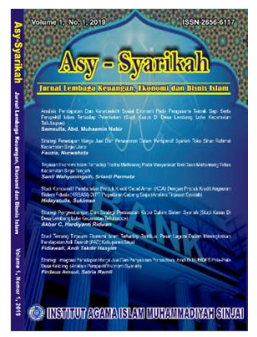

Asy-Syarikah

Jurnall Lembaga Keuangan, Ekonomi dan Bisnis Islam

Volume 3, No. 1, 2021

ISSN (print) : 2656-6117

ISSN (online) : 2715-0356

Homepage : http://journal.iaimsinjai.ac.id/index.php/asy-syarikah

\title{
FORMULASI KONSEP KELOMPOK SIMPAN PINJAM KHUSUS PEREMPUAN PROGRAM NASIONAL PEMBERDAYAAN MASYARAKAT MANDIRI PEDESAAN (PNPM-MP) DALAM PERSPEKTIF EKONOMI SYARIAH
}

\author{
Andi Musdalipah ${ }^{\mathbf{1}}$, Hj. Hukmiah ${ }^{2}$, Sitti Nikmah Marzuki, ${ }^{3}$ \\ ${ }^{1}$ Institut Agama Islam Negeri Bone, Tellu Limpoe, Kab. Bone \\ ${ }^{2}$ Institut Agama Islam Negeri Bone, Tanete Riattang Barat, Kab. Bone \\ ${ }^{3}$ Institut Agama Islam Negeri Bone, Tanete Riattang Barat, Kab. Bone \\ E-mail:_musdalipah.andi.88@gmail.com,Tlp:+6282317077947
}

\begin{abstract}
Abstrak
Kegiatan Simpan Pinjam Khusus Perempuan Program Nasional Pemberdayaan Masyarakat Mandiri Pedesaan (PNPM-MP) merupakan kegiatan pemberian permodalan untuk kelompok perempuan yang memiliki kegiatan simpan pinjam atau kegiatan usaha ekonomi, sebagai alternatif pemecahan permasalahan kemiskinan di pedesaan. Program Simpan Pinjam Khusus Perempuan memberikan permodalan bagi kelompok perempuan yang menjalankan kegiatan simpan pinjam dengan tingkat suku bunga yang lebih rendah dari pada Bank, hal tersebut diharapkan dapat membantu masyarakat terutama kaum perempuan untuk dapat meningkatkan taraf hidup dengan mengembangkan usaha yang dikelola. Adapun pokok permasalahan dalam penelitian ini adalah mengkaji serta menjelaskan formulasi konsep pengelolaan simpan pinjam khusus perempuan Program Nasional Pemberdayaan Masyarakat Mandiri Pedesaan (PNPM-MP) berbasiskan ekonomi syariah. Jenis penelitian ini merupakan deskriptif kualitatif. Penelitian ini menggunakan pendekatan sosiologis, ekonomi dan yuridis dalam mengumpulkan data yang diperlukan. Data yang telah terkumpul kemudian diolah dengan menggunakan analisis metode induksi, deduksi dan komparasi. Formulasi konsep pengelolaan kelompok simpan pinjam khusus perempuan Program Nasional Pemberdayaan Masyarakat Mandiri Pedesaan (PNPM-MP) adalah adanya perubahan kebijakan pemerintah, sehingga mengakibatkan perguliran dana di masyarakat tidak berjalan sesuai hakikat pemberdayaan. Sehingga, hal tersebut diperlukan perumusan konsep melalui pendekatan Ekonomi Syariah.
\end{abstract}

Kata Kunci : Formulasi, PNPM-MP, Pemberdayaan, Penghambat, Ekonomi Syariah.

\section{Pendahuluan}

Pemerintah Indonesia mencanangkan Program Nasional Pemberdayaan Masyarakat (PNPM) mandiri sejak tahun 2007 yang terdiri dari PNPM Mandiri Perdesaan, PNPM Mandiri Perkotaan, serta PNPM Wilayah Khusus dan Desa Tertinggal. PNPM Mandiri Perdesaan adalah program untuk mempercepat penanggulangan kemiskinan secara terpadu dan berkelanjutan. Khusus untuk 


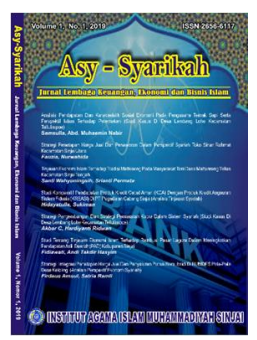

Asy-Syarikah

Jurnall Lembaga Keuangan, Ekonomi dan Bisnis Islam

Volume 3, No. 1, 2021

ISSN (print) : 2656-6117

ISSN (online) : 2715-0356

Homepage : http://journal.iaimsinjai.ac.id/index.php/asy-syarikah

pengembangan PNPM Mandiri Perdesaan dilakukan dengan dasar Surat Keputusan Menkesra Nomor 25/Kep/Menko/Kesra/VII 2007 tanggal 30 Juli 2007, di tindak lanjuti dengan kebijakan ditingkat Provinsi/ Kabupaten/ Kota.

Pelaksanaan PNPM Mandiri diarahkan untuk meningkatkan efektivitas penanggulangan kemiskinan dan penciptaan lapangan kerja dengan melibatkan unsur masyarakat mulai dari tahap perencanaan, pelaksanaan, hingga pemantauan dan evaluasi.

Simpan Pinjam Khusus Perempuan (SPP) adalah salah satu program dari PNPM-MP, sebagai alternatif pemecahan permasalahan kemiskinan di pedesaan, program Simpan Pinjam Khusus Perempuan (SPP) memberikan permodalan bagi kelompok perempuan yang menjalankan kegiatan simpan pinjam dengan tingkat suku bunga yang lebih rendah dari pada Bank, hal tersebut diharapkan dapat membantu masyarakat terutama kaum perempuan untuk dapat meningkatkan taraf hidup dengan mengembangkan usaha yang dikelola.

Oleh karena itu, kemiskinan perlu ditangani secara terpadu, terencana dan berkesinambungan. Program Nasional Pemberdayaan Masyarakat (PNPM) Mandiri Pedesaan merupakan salah satu program pembangunan yang berfungsi untuk meningkatkan efektivitas penanggulangan kemiskinan dan penciptaan lapangan kerja ditingkat perdesaan dan perkotaan yang diluncurkan oleh pemerintah Indonesia.

Pemberdayaan masyarakat adalah sebuah pendekatan yang memberikan kesempatan, wewenang yang lebih besar kepada masyarakat terutama masyarakat lokal untuk mengelola proses pembangunan ${ }^{1}$.

Implementasi Program Simpan Pinjam Khusus Perempuan di Indonesia mulai beroperasi sejak tahun 2007 sampai sekarang. Namun, memiliki kendala sejak Pemerintahan Presiden Republik Indonesia Tahun 2014 karena adanya pergeseran kegiatan - kegiatan pada pos anggaran dana Desa. Sehingga, kegiatan -

1 Soetomo, Pemberdayaan Masyarakat Mungkinkah Muncul Antitesisnya? , (Cet. 1; Yogyakarta: Pustaka Pelajar, 2011), h. 69. 


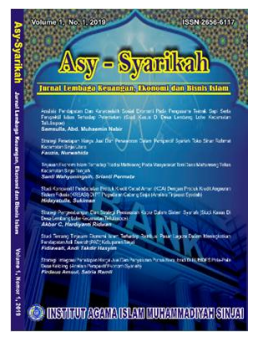

Asy-Syarikah

Jurnall Lembaga Keuangan, Ekonomi dan Bisnis Islam

Volume 3, No. 1, 2021

ISSN (print) : 2656-6117

ISSN (online) : 2715-0356

Homepage : http://journal.iaimsinjai.ac.id/index.php/asy-syarikah

kegiatan yang sebelumnya berjalan dengan baik mengalami kendala pengaturan dan juga kendala konsep pengelolaaan. ${ }^{2}$

Selain permasalahan tersebut, juga adanya kendala tunggakan oleh para Kelompok Simpan Pinjam Khusus Perempuan, karena akad perjanjian yang dilakukan pada saat peminjaman tidak adanya jaminan khusus sesuai agunan, sehingga hal tersebut tidak mengikatkan antara pengelola dan peminjam dalam hal ini Kelompok Simpan Pinjam Khusus Perempuan yang di kelola oleh Unit Pengelola Kegiatan PNPM-MP.

Unit Pengelola Kegiatan (UPK) sebagai pengelola dana program percepatan penanggulangan kemiskinan dengan pola pemberdayaan masyarakat yang berbasis kecamatan (desa dan kelurahan) berupa Bantuan Langsung Masyarakat (BLM) sebagaimana diatur dalam Permenkeu Nomor 148/PMK.07/2009) yang bersumber dari Dana Urusan Bersama sebagaimana tertuang dalam Permenkeu Nomor 168/PMK.07.2009) disalurkan melalui Belanja Anggaran Bantuan Sosial yang diatur dalam Peraturan Presiden Nomor 15 Tahun 2010.

Visi PNPM Mandiri Perdesaan adalah tercapainya kesejahteraan dan kemandirian masyarakat miskin perdesaan. Kesejahteraan berarti terpenuhinya kebutuhan dasar masyarakat.

Kemandirian berarti mampu mengorganisir diri untuk memobilisasi sumberdaya yang ada di lingkungannya, mampu mengakses sumber daya di luar lingkungannya, serta mengelola sumber daya tersebut untuk mengatasi masalah kemiskinan.

Misi PNPM Mandiri Perdesaan adalah: ${ }^{3}$

1) Peningkatan kapasitas masyarakat dan kelembagaannya.

2) Pelembagaan sistem pembangunan partisipatif.

3) Pengefektifan fungsi dan peran pemerintahan lokal.

4) Peningkatan kualitas dan kuantitas sarana prasarana sosial dasar dan ekonomi masyarakat.

5) Pengembangan jaringan kemitraan dalam pembangunan.

2 Hasil observasi langsung penulis yang didasari Surat Permohonan Pribadi ke Unit Pengelola Kegiatan Program Nasional Pemberdayaan Masyarakat Mandiri Pedesaan (PNPM-MP) Kecamatan Lappariaja, Pada hari Senin, 11 Januari 2021.

3 Di kutip dari pnpm-mandiri.org/\#, 


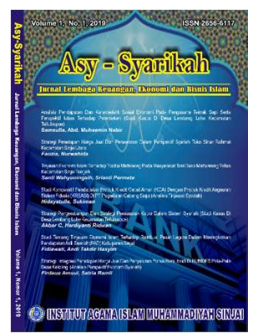

Asy-Syarikah

Jurnall Lembaga Keuangan, Ekonomi dan Bisnis Islam

Volume 3, No. 1, 2021

ISSN (print) : 2656-6117

ISSN (online) : 2715-0356

Homepage : http://journal.iaimsinjai.ac.id/index.php/asy-syarikah

Untuk mencapai visi dan misi PNPM Mandiri Perdesaan, strategi yang dikembangkan PNPM Mandiri Perdesaan yaitu menjadikan rumah tangga miskin (RTM) sebagai kelompok sasaran, menguatkan sistem pembangunan partisipatif, serta mengembangkan kelembagaan kerja sama antar desa.

Semestinya, program tersebut terus bergulir karena konsep tujuan dan sasarana pemberdayaan dapat diartikan sebagai suatu proses yang membangun manusia atau masyarakat melalui pengembangan kemampuan masyarakat, merubah perilaku masyarakat dan pengorganisasian masyarakat serta untuk pencapaian tujuan utama pemberdayaan, yakni mengembangkan kemampuan masyarakat, mengubah perilaku masyarakat dan mengorganisir diri masyarakat.

Berdasarkan uraian dari latar belakang tersebut, Penulis akan mengkaji dalam karya tulis ilmiah dengan judul Formulasi Konsep Kelompok Simpan Pinjam Khusus Perempuan Program Nasional Pemberdayaan Masyarakat Mandiri Pedesaan (PNPM-MP) di Kecamatan Lappariaja, Kabupaten Bone (Perspektif Ekonomi Syariah).

\section{Metode}

\section{1. Jenis Penelitian}

Penelitian ini termasuk dalam jenis penelitian deskriptif kualitatif, dengan tujuan agar peneliti dapat menggambarkan fenomena dan fakta yang terjadi dalam pelaksanaan Program Nasional Pemberdayaan Masayarakat Mandiri Pedesaan (PNPM-MP) pada Kelompok Simpan Pinjam Khusus Perempuan di Kecamatan Lappariaja.

\section{2. Pendekatan Penelitian}

\section{a. Pendekatan Sosilogis}

Pendekatan sosiologis digunakan sebagai salah satu pendekatan dalam memahami kondisi sosial dan permasalahan yang ada dalam kehidupan masyarakat pelaku PNPM-MP pada Kelompok Simpan Pinjam Khusus Perempuan untuk mendapatkan data dan informasi terkait permasalahan yang dialami demi 


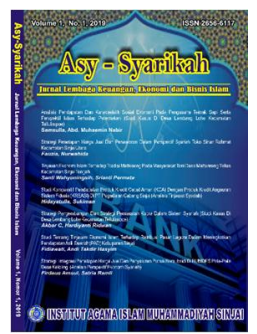

Asy-Syarikah

Jurnall Lembaga Keuangan, Ekonomi dan Bisnis Islam

Volume 3, No. 1, 2021

ISSN (print) : 2656-6117

ISSN (online) : 2715-0356

Homepage : http://journal.iaimsinjai.ac.id/index.php/asy-syarikah

perumusan konsep maupun pengelolaan PNPM-MP melalui pendekatan Ekonomi Syariah.

\section{b. Pendekatan Ekonomi}

Pendekatan ekonomi ini digunakan untuk mempelajari berbagai perilaku pelaku ekonomi yang dijalankan melalui pembiayaan atau program PNPM-MP pada Kelompok Simpan Pinjam Khusus Perempuan.

\section{c. Pendekatan Yuridis}

Pendekatan ini merupakan desain deskriptif kualitatif untuk menggambarkan Rekonstruksi PNPM-MP Pada Kelompok Simpan Pinjam Khusus Perempuan dalam Perspektif Ekonomi Syariah.

\section{3. Metode Pengumpulan Data}

Metode studi pustaka ini di gunakan untuk mengumpulkan data yang di perlukan dengan cara membaca :

1) Buku yang terkait dengan pembahasan;

2) Peraturan Perundang-undangan;

3) Jurnal ilmiah;

4) Literatur yang berhubungan dengan masalah yang akan di bahas.

\section{4. Metode Pengolahan dan Analisa Data}

Data yang telah dikumpulkan dan dipahami, kemudian dianalisis dengan menggunakan :

1) Induksi yaitu cara menarik kesimpulan dari hal-hal yang bersifat khusus ditarik ke hal-hal yang bersifat umum, yakni berfikir dari fakta yang bersifat khusus kemudian ditarik kesimpulan yang bersifat umum.

2) Deduksi yaitu cara menarik kesimpulan dari hal-hal yang bersifat umum ditarik ke hal-hal yang bersifat khusus. Metode ini digunakan untuk menganalisa data dengan berfikir dari pengetahuan yang bersifat umum, selanjutnya menulis suatu kejadian yang bersifat khusus.

3) Komparasi yaitu peneliti mengadakan perbandingan dari beberapa pendapat yang berbeda dari sumber yang di wawancarai untuk mencari yang lebih kuat atau untuk mencapai kemungkinan dalam pengkomparasikan.

\section{Hasil dan Pembahasan}

\section{A. Teori Formulasi}




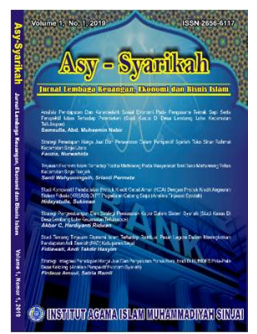

Asy-Syarikah

Jurnall Lembaga Keuangan, Ekonomi dan Bisnis Islam

Volume 3, No. 1, 2021

ISSN (print) : 2656-6117

ISSN (online) : 2715-0356

Homepage : http://journal.iaimsinjai.ac.id/index.php/asy-syarikah

Landasan teoritis merupakan rumusan yang dibuat berdasarkan proses berfikir deduktif dalam rangka menghasilkan konsep dan proposisi baru.

Bangunan teori adalah abstrak dari sejumlah konsep yang disepakatkan dalam definisi-definisi. Konsep sebagai abstraksi dari banyak empiri yang telah ditemukan kesamaan umumnya dan kepilahannya dari yang lain atau abstraksi dengan cara menemukan sejumlah esensi pada suatu kasus, dan dilakukan berkelanjutan pada kasus-kasus lainnya, dapat dikonstruksikan lebih jauh menjadi proposisi atau pernyataan, dengan membuat kombinasi dari dua konsep atau lebih.

Penerimaan suatu teori di dalam komunitas ilmiah, tidak berarti bahwa teori tersebut memiliki kebenaran mutlak. Setiap teori selalu sudah dipengaruhi oleh pengandaian-pengandaian dan metode dari ilmuwan yang merumuskannya. Kemampuan suatu teori untuk memprediksi apa yang akan terjadi merupakan kriteria bagi validitas teori tersebut. Semakin prediksi dari teori tersebut dapat dibuktikan, semakin besar pula teori tersebut akan diterima di dalam komunitas ilmiah ${ }^{4}$.

Paradigma adalah cara pandang atau kerangka berpikir yang berdasarkannya fakta atau gejala diinterpretasi dan dipahami. Para ilmuwan bekerja dalam kerangka seperangkat aturan yang sudah dirumuskan secara jelas berdasarkan paradigma dalam bidang tertentu, sehingga pada dasarnya solusinya sudah dapat diantisipasi terlebih dahulu. Jika dalam perjalanan kegiatannya timbul hasil yang tidak diharapkan, atau penyimpangan dari paradigmanya yang oleh Kuhn disebut sebagai anomaliakan menyebabkan perubahan paradigma karena adanya anomaly itu kemudian menyebabkan sikap ilmuawan terhadap paradigma yang berlaku berubah, oleh karena itu sifat penelitian mereka juga berubah.

Formulasi kebijakan menurut Winarno (2007) adalah sebagai suatu proses masalah yang masuk ke agenda kebijakan dan kemudian dibahas oleh para aktor pembuat kebijakan. Pada tahap perumusan kebijakan, masing-masing alternatif

4 Reza A.A Wattimena. 2008. Filsafat dan Sains Sebuah Pengantar. (Jakarta : PT. Grasindo). h .95. 
Homepage $\quad$ : http://journal.iaimsinjai.ac.id/index.php/asy-syarikah

bersaing untuk dapat dipilih sebagai kebijakan yang diambil untuk memecahkan suatu masalah. ${ }^{5}$

\section{B. Konsep Pemberdayaan}

Dalam Kamus Besar Bahasa Indonesia (KBBI), kata pemberdayaan berasal dari suku kata daya yang berarti kemampuan untuk melakukan sesuatu atau tindakan (tidak mencapai suatu maksud, pemecahan persoalan, mencari jalan keluar). ${ }^{6}$ Pemberdayaan dijelaskan sebagai usaha (syarat) suatu cara, proses pemberdayaan suatu kemampuan yang dimiliki seseorang sebagai suatu kegiatan yang dilakukan secara sistematis, terencana dan terarah untuk memajukan apa yang diinginkan oleh masyarakat.

Istilah pemberdayaan semakin popular dalam konteks pembangunan dan pengentasan kemiskinan. Konsep pemberdayaan ini berkembang dari realitas individu atau masyarakat yang tidak berdaya atau pihak yang lemah. Ketidakberdayaan atau memiliki kelemahan dalam aspek: pengetahuan, pengalaman, sikap, keterampilan, modal usaha, networking, kerja keras, ketekunan dan aspek lainnya. Konsep pemberdayaan masyarakat jika ditelaah sebenarnya berangkat dari pandangan yang ditempatkan manusia sebagai subjek dari dunianya sendiri. Pola dasar gerakan pemberdayaan ini mengamanatkan kepada perlunya power dan menekankan keberpihakan kepada kelompok yang berdaya. ${ }^{7}$

Pemberdayaan masyarakat merupakan strategi pembangunan.. Sebagai suatu strategi pembangunan pemberdayaan dapat diartikan sebagai kegiatan membantu klien untuk memproleh daya, guna mengambil keputusan dan menentukan tindakan yang akan dilakukan, terkait dengan diri mereka termasuk mengurangi hambatan pribadi dan sosial dalam melakukan tindakan melalui peningkatan kemampuan dan rasa percaya diri untuk menggunakan daya yang dimiliki dengan mentransfer daya

5 Dikuti dari https:// www. google. Com /search?q =teori +formulasi + kebijakan \& $\underline{\mathrm{oq}}=$ Teori+formulasi+kebijakan. Senin, 14 Maret 2021

6 Departemen Pendidikan Nasional, KBBI Edisi Ketiga, (Jakarta: Balai Pustaka, 2007), h. 121.

7 Zubaedi, Pengembangan Masyarakat: Wacana dan Praktik, (Jakarta: Pernada Media Group, 2013), h. 72. 
dari lingkungannya.

Sementara itu, Ife memberikan batasan pemberdayaan sebagai upaya penyediaan kepada orang-orang atas sumber, kesempatan, pengetahuan, dan keterampilan untuk meningkatkan kemampuan mereka menentukan masa depannya dan untuk berpartisipasi dan mempengaruhi kehidupan komunitas mereka ${ }^{8}$.

Kecenderungan pertama tersebut dapat disebut sebagai kecenderungan primer dari makna pemberdayaan. Sedangkan kecenderungan kedua atau kecenderungan sekunder menekankan pada proses menstimulasi, mendorong atau memotivasi individu agar mempunyai kemampuan atau keberdayaan untuk menentukan apa yang menjadi pilihan hidupnya melalui proses dialog. ${ }^{9}$ Lebih lanjut, Sumardjo menyebutkan cirri-ciri masyarakat berdaya yaitu:

1) Mampu memahami diri dan potensinya, mampu merencanakan (mengantisipasi kondisi perubahan kedepan).

2) Mampu mangarahkan dirinya sendiri.

3) Memiliki kekuatan untuk berunding.

4) Memiliki bargaining power yang memadai dalam melakukan kerjasama yang saling menguntungkan, dan bertanggung jawab atas tindakannya.

Tabel : Laporan Perkembangan Pinjaman Simpan Pinjam Khusus Perempuan PNPM Mandiri Pedesaan, Kecamatan Lappariaja. ${ }^{10}$

\begin{tabular}{|l|l|l|l|l|}
\hline NO & DESA & $\begin{array}{l}\text { JUMLAH } \\
\text { KELOMPOK } \\
\text { SPP }\end{array}$ & $\begin{array}{l}\text { ALOKASI } \\
\text { PINJAMAN }\end{array}$ & TUNGGAKAN \\
\hline 1. & Sengeng Palie & 4 & Rp. 168.900 .000 & Rp. 634.000 \\
\hline 2. & Tenri Pakkua & 7 & Rp. 289.711.000 & Rp. 68.694.329 \\
\hline 3. & Lili Riattang & 9 & Rp. 338.575.500 & Rp. 4.157.000 \\
\hline
\end{tabular}

\footnotetext{
${ }^{8}$ Burhan Bungin, Sosiologi Komunikasi, Teori Paradigma dan Diskursus teknologi komunikasi di masyarakat, (Jakarta: Kencana Pranada Media Grup, 2006), h. 29.

${ }^{9}$ Hany Hikmat, Strategi Pemberdayaan Masyarakat, (Cet. 2; Bandung: Humaniora Utama Press, 2004), h. 8.

10 Hasil observasi langsung di Kantor Unit Pengelola Kegiatan PNPM-MP Kecamatan Lappariaja
} 


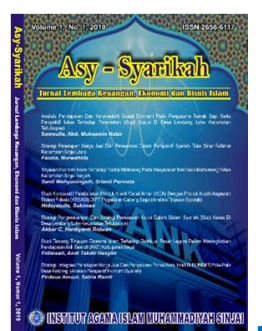

Asy-Syarikah

Jurnall Lembaga Keuangan, Ekonomi dan Bisnis Islam

Volume 3, No. 1, 2021

ISSN (print) : 2656-6117

ISSN (online) : 2715-0356

Homepage : http://journal.iaimsinjai.ac.id/index.php/asy-syarikah

\begin{tabular}{|l|l|l|l|l|}
\hline 4. & Waekecc'e & 2 & Rp. 65.713.000 & Rp. 3.948.000 \\
\hline 5. & $\begin{array}{l}\text { Pattuku } \\
\text { Limpoe }\end{array}$ & 4 & Rp. 176.000.000 & Rp. 25.378.002 \\
\hline 6. & Patangkai & 18 & Rp. 559.526.000 & Rp. 133.557.053 \\
\hline 7. & Ujung Lamuru & 17 & Rp. 731.655.000 & Rp. 334.317.216 \\
\hline 8. & $\begin{array}{l}\text { Mattampa } \\
\text { Walie }\end{array}$ & 4 & Rp. 195.000.000 & Rp. 35.307.999 \\
\hline 9. & Tonronge & 1 & Rp. 25.000.000 & Rp. 13.509.330 \\
\hline & TOTAL & $\mathbf{6 6}$ & Rp. 2.550.080.500 & Rp. 619.448.929 \\
\hline
\end{tabular}

Menganalisis Laporan Perkembangan Pinjaman Simpan Pinjam Khusus

Perempuan (SPP) pada Program Nasional Pemberdayaan Masyarakat Mandiri Pedesaan (PNPM-MP), Kecamatan Lappariaja tersebut, Penulis menganalisisnya bahwa terdapat dana Rp. 2.550.080.500,- yang digulirkan ke masyarakat oleh pengelola yang terbagi kedalam 66 Kelompok Simpan Pinjam Khusus Perempuan (SPP). Adapun dana menunggak hingga Januari 2021 sebanyak Rp. 619.448.929,--

Perkembangan jumlah kelompok Simpan Pinjam Khusus Perempuan (SPP) di Kecamatan Lappariaja juga mengalami stagnasi atau tidak mengalami perkembangan pesat di bandingkan pada pengelolaan sebelum Tahun 2014. Hal tersebut karena fokus perhatian pemerintah baik pemerintah pusat maupun daerah tidak lagi memfokuskan pada pengelolaan Simpan Pinjam Khusus Perempuan (SPP).

Semestinya, program tersebut terus bergulir karena konsep tujuan dan sasarana pemberdayaan dapat diartikan sebagai suatu proses yang membangun manusia atau masyarakat melalui pengembangan kemampuan masyarakat, merubah perilaku masyarakat dan pengorganisasian masyarakat serta untuk pencapaian tujuan utama pemberdayaan, yakni mengembangkan kemampuan masyarakat, mengubah perilaku masyarakat dan mengorganisir diri masyarakat. 


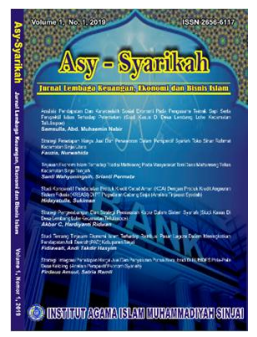

Asy-Syarikah

Jurnall Lembaga Keuangan, Ekonomi dan Bisnis Islam

Volume 3, No. 1, 2021

ISSN (print) : 2656-6117

ISSN (online) : 2715-0356

Homepage : http://journal.iaimsinjai.ac.id/index.php/asy-syarikah

Tugas pelaku pemberdayaan adalah mendorong dan menciptakan individu serta masyarakat untuk mampu melakukan perubahan perilaku untuk menuju kearah kemandirian (berdaya). Perubahan perilaku ini baik aspek pengetahuan, sikap, maupun keterampilan yang berguna untuk meningkatkan kualitas kehidupan dan kesejahteraannya. Oleh karena itu, petugas yang memberdayakan individu dan masyarakat baik formal maupun non formal dapat disebutkan sebagai agen pemberdayaan (agent of empowerment).

\section{Teori Pinjaman}

Secara sederhana, pinjaman dapat diartikan sebagai barang atau jasa yang menjadi kewajiban pihak yang satu untuk dibayarkan kepada pihak lain sesuai dengan perjanjian tertulis ataupun lisan, yang dinyatakan atau diimplikasikan serta wajib dibayarkan kembali dalam jangka waktu tertentu.

Sementara dalam kajian bahasa arab ada beberapa istilah untuk penyebutan pinjam meminjam atau utang piutang yakni dain, ariyah, dan qard yang pada dasarnya adalah sama. ${ }^{11}$ Kamus bahasa Indonesia mendefinisikan utang adalah "uang yang dipinjam dari orang lain; kewajiban membayar kembali apa yang sudah diterima". Sedangkan piutang adalah "uang yang dipinjamkan kepada orang lain (dapat ditagih dari orang lain)".

Menurut etimologi kata Al Ariyah menggunakan tasydid pada huruf yaa", bermakna suatu yang dipinjamkan, pergi dan beredar. Asal kata 'ariyah adalah kata kerja yang berbunyi fathah pada huruf 'ain. Al Azhari berkata : Al Ariyah adalah nisbat kepada al 'arah, merupakan isim dari kata i'arah.

Secara Istilah Pinjaman adalah kewenangan pengambilan manfaat suatu barang secara halal serta wujud barangnya tetap utuh ketika dikembalikan. ${ }^{12}$ Maka utang atau pinjaman adalah aqad serah terima uang yang dilakukan dua pihak dimana pihak kedua atau yang berhutang wajib mengembalikan sejumlah uang yang sama yang telah diterima. ${ }^{13}$ Adapun dasar hukum Pinjaman sebagaimana tercantum dalam QS. Al-

11 Dalam bahasa Arab, utang disebut dengan dain, sedangkan agama disebut din, dimana keduanya berasal dari akar kata yang sama; dal-ya-nun.

12 Wahbah Zuhaili, Fiqih Imam Syafi'i, (Cet. 2; Jakarta: Almahira, 2012), h. 239. 86.

Dede Rodin, Tafsir Ayat Ekonomi, (Cet. 1; Semarang: CV. Karya Abadi Jaya, 2015), h. 


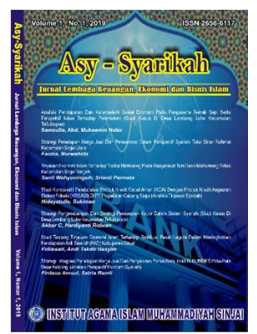

Asy-Syarikah

Jurnall Lembaga Keuangan, Ekonomi dan Bisnis Islam

Volume 3, No. 1, 2021

ISSN (print) : 2656-6117

ISSN (online) : 2715-0356

Homepage : http://journal.iaimsinjai.ac.id/index.php/asy-syarikah

Baqarah (2) : 245 :

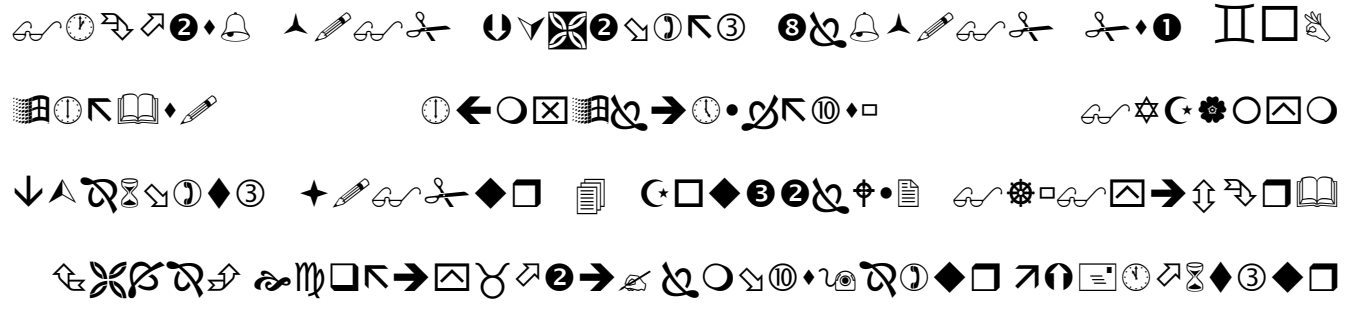

Terjemahan : Siapakah yang mau memberi pinjaman kepada Allah, pinjaman yang baik (menafkahkan hartanya di jalan Allah), Maka Allah akan meperlipat gandakan pembayaran kepadanya dengan lipat ganda yang banyak. dan Allah menyempitkan dan melapangkan (rezki) dan kepada-Nya-lah kamu dikembalikan.

Selanjutnya, dalam Qur"an Surah An-Nisa"( (4): 58)

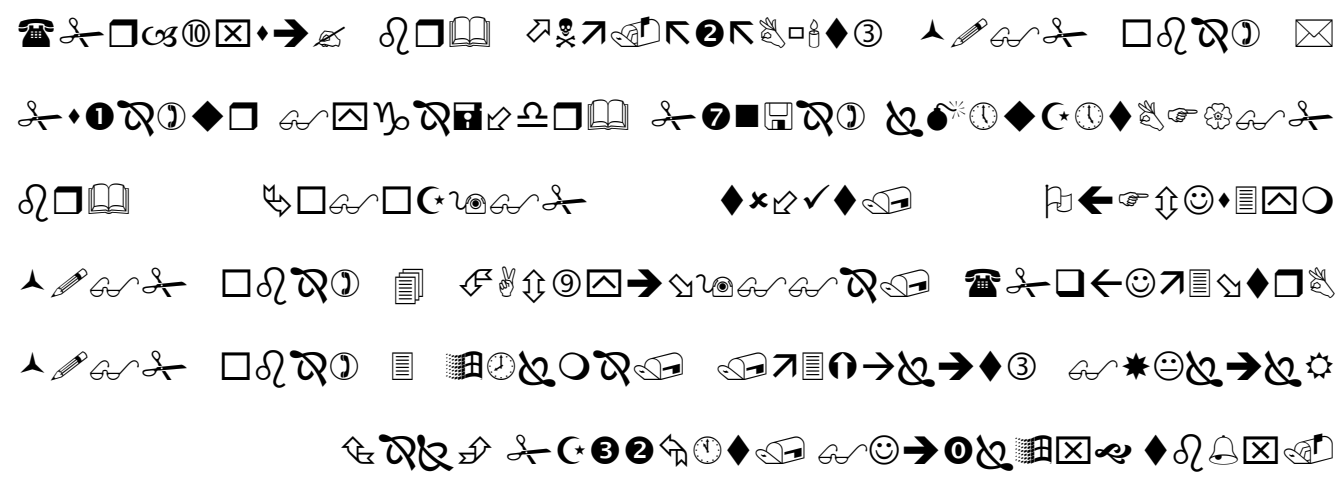

Terjemahan : Sesungguhnya Allah menyuruh kamu menyampaikan amanat kepada yang berhak menerimanya, dan (menyuruh kamu) apabila menetapkan hukum di antara manusia supaya kamu menetapkan dengan adil. Sesungguhnya Allah memberi pengajaran yang sebaik-baiknya kepadamu. Sesungguhnya Allah adalah Maha mendengar lagi Maha Melihat.

Dalam Hadis juga di jelaskan bahwa Rasulullah SAW bersabda :

Seorang muslim adalah saudara muslim lainnya. Ia tidak boleh mendzaliminya dan menganiayanya. Barang siapa yang membantu kebutuhan saudaranya, maka Allah akan memenuhi kebutuhanya. Barang siapa yang membebaskan kesulitan seorang muslim maka Allah akan membebaskanya dari kesulitan pada hari kiamat. Dan barang siapa menutupi aib seorang muslim, maka Allah akan menutupi aibnya pada hari kiamat kelak." (HR. Muslim).

Ayat-ayat dan Hadis tersebut menjelaskan tentang anjuran meminjamkan yang baik kepada Allah, yaitu dengan menafkahkan harta dijalan Allah yang berupa infaq, shadaqah, termasuk juga memberi pinjaman kepada orang yang sedang 
membutuhkan.

Penggunaan istilah "pinjaman yang baik" di dalam Al- Qur"an guna memotivasi untuk berinfaq pada jalan kebaikan. Pinjaman yang baik disini berarti memberi pinjaman dengan niat yang bersih, hati yang tulus, serta harta yang halal. ${ }^{14}$

\section{Tinjauan Ekonomi Islam}

Ekonomi Islam telah menjadi pembahasan tersendiri pada masa modern saat ini. Kajian-kajian telah banyak dilakukan oleh para ulama mengingat pada masa awal pertumbuhan Islam, ekonomi Islam belum muncul sebagai sebuah disiplin keilmuan. Meskipun demikian, pondasi atu landasan dasarnya telah terealisasi dalam sejarah Islam, sehingga hal inilah yang merupakan warisan yang terus menjadi sumber bagi berkembangnya nilai-nilai ekonomi Islam. Ulama berperan besar dalam memberikan penjelasan kepada para pelaku ekonomi dalam menjalankan kegiatan muamalahnya.

Sesungguhnya mengkaji ekonomi Islam bukanlah dominasi para ekonom. Tetapi kajian ekonomi Islam hendaknya dilakukan para pakar Islam yang menguasai pandangan Islam dengan segala aspeknya yang sempurna. Kemudian setelah ini, baru pengkajian berpindah pada para spesialis. Spesialis perekonomian merumuskan sistem perekonomian dengan tetap membuat pandangan Islam sebagai landasan dan acuan dasar. Pandangan Islam meliputi syariahnya, yang berkait dengan sistem perekonomian maupun yang berkait dengan sosial kemasyarakatan.

Islam merupakan ajaran Ilahi yang bersifat integral (menyatu) dan komperehensif (mencakup segala aspek kehidupan). Oleh sebab itu, Islam harus dilihat dan diterjemahkan dalam kehidupan sehari-hari secara koprehensif pula. Semua pekerjaan atau aktivitas dalam Islam, termasuk aktivitas ekonomi, harus tetap dalam bingkai akidah dan syari'ah.

Aktivitas ekonomi dalam bingkai akidah maksudnya adalah usaha yang dilakukan oleh seorang muslim harus diniatkan dalam rangka ibadah kepada Allah dengan penuh keikhlasan, kesabaran dan isti'anah (memohon

\footnotetext{
14 M. Quraish Shihab, Tafsir al-Misbah, (Vol.1; Jakarta: Lentera Hati, 2002), h. 640.
} 


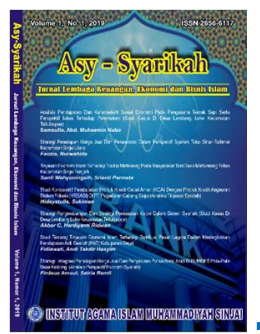

Asy-Syarikah

Jurnal Lembaga Keuangan, Ekonomi dan Bisnis Islam

Volume 3, No. 1, 2021

ISSN (print) : 2656-6117

ISSN (online) : 2715-0356

Homepage : http://journal.iaimsinjai.ac.id/index.php/asy-syarikah

pertolongan Allah). Sedangkan aktivitas ekonomi dalam bingkai syariah (menurut aturan Allah) maksudnya, dalam melakukan aktivitas ekonomi seseorang harus menyesuaikan diri dengan aturan Alquran dan hadis. Interaksi ekonomi dengan segala bentuknya senantiasa berkembang mengikuti perkembangan zaman dan tingkat kemajuan kebudayaan manusia. Sehingga, semakin berkembang kebudayaan manusia semakin banyak jenis muamalah yang muncul. Meskipun demikian, tentu tidak berarti bahwa nilai-nilai atau norma Islam luput dari persoalan ekonomi yang berkembang di zaman sekarang, dan yang akan datang.

Namun, dalam banyak hal terkait dengan keuangan, Islam memiliki beberapa prinsip yang membedakannya dengan sistem ekonomi lain :
a. Prinsip Tauhid
b. Prinsip Keadilan
c. Prinsip Maslahat
d. Prinsip Ta'awun (tolong-menolong)
e. Prinsip Keseimbangan

Untuk mencapai kemaslahatan yang seimbang dan holistik dalam berbagai aspek kehidupan manusia yang merupakan tujuan ekonomi dalam Islam, Islam memberi rambu-rambu yang jelas dalam melakukan interaksi dan transaksi. Misalnya, kegiatan ekonomi dilandasi tauhid, adil, asas kebolehan dan kebebasan, berorientasi pada kemaslahatan, bebas dari riba (eksploitasi manusia), jelas; objek, harga, dan nilainya.

\section{Simpulan}

Berdasarkan hasil pembahasan yang telah dilakukan, maka dapat ditarik kesimpulan bahwa pengelolaan konsep kelompok simpan pinjam khusus perempuan Program Nasional Pemberdayaan Masyarakat Mandiri Pedesaan (PNPM-MP) di Kecamatan Lappariaja, Kabupaten Bone di perlukan sebuah formulasi yang dapat mewujudkan hakikat pemberdayaan berbasiskan nilai- nilai Ekonomi Syariah. Prinsip Ekonomi Syariah yang dapat di terapkan dalam konsep kelompok simpan pinjam khusus perempuan diantaranya Prinsip Keadilan, Prinsip Maslahat dan Prinsip Ta'awun (tolong-menolong). 
Buku:

Burhan Bungin. 2006. Sosiologi Komunikasi, Teori Paradigma dan Diskursus teknologi komunikasi di Masyarakat, Jakarta: Kencana Pranada Media Grup.

Dede Rodin, 2015. Tafsir Ayat Ekonomi, Cet. 1; Semarang: CV. Karya Abadi Jaya.

Departemen Pendidikan Nasional. 2007. KBBI Edisi Ketiga, Jakarta: Balai Pustaka

Hany Hikmat, 2004. Strategi Pemberdayaan Masyarakat, Cet. 2; Bandung: Humaniora Utama Press.

M. Quraish Shihab, 2002. Tafsir al-Misbah, Vol.1; Jakarta: Lentera Hati.

Naf"an, 2014. Pembiayaan Musyarakah dan Mudharabah, Cet. 1; Yogyakarta: Graha Ilmu.

Reza A.A Wattimena. 2008. Filsafat dan Sains Sebuah Pengantar. Jakarta : PT. Grasindo.

Soetomo, 2011. Pemberdayaan Masyarakat Mungkinkah Muncul Antitesisnya?, Cet. 1; Yogyakarta: Pustaka Pelajar.

Wahbah Zuhaili. 2012. Fiqih Imam Syafi'i, Cet. 2; Jakarta: Almahira.

Zubaedi. 2013. Pengembangan Masyarakat: Wacana dan Praktik, Jakarta: Pernada Media Group.

\section{Dokumen dari internet:}

Wikipedia (2021), di kutip dari pnpm-mandiri.org/\#

Wikipedia (2021) dikuti dari https:// www. google. Com /search?q=teori +formulas i+kebijakan \& oq=Teori+formulasi+kebijakan. 